\title{
ANALISIS TANTANGAN DAN KESEMPATAN MENGGUNAKAN MUSIK TRADISIONAL DALAM IBADAH KRISTEN
}

\author{
Rahel Sermon Harapani Daulay \\ Sekolah Tinggi Filsafat Theologi Jakarta \\ daulayrahel@gmail.com
}

\begin{abstract}
Abstrak
Musik tradisional saat ini menjadi hal yang menarik untuk didiskusikan, secara khusus ketika dikaitkan dengan ibadah Kristen. Apakah musik tradisional tepat atau masih relevan digunakan di dalam ibadah? Pertanyaan seperti ini sering kali muncul dalam diskusi dan jawaban untuk pertanyaan ini tidaklah mudah, oleh karena banyak sekali perspektif dan pendekatan disiplin ilmu yang harus ditelaah dalam rangka menghadirkan jawaban yang tepat. Penelitian dalam tulisan ini untuk memperlihatkan tantangan dan peluang penggunaan musik tradisional, ditinjau dari sisi teologis maupun musikologis. Penulis menggunakan Gereja dan Sekolah Tinggi Teologi sebagai lingkup penelitian, oleh karena kedua lembaga ini merupakan wadah di mana proses edukasi dapat diterapkan sekaligus dapat membawa pengaruh yang lebih luas. Untuk mengumpulkan data yang terjadi di lapangan, penulis melakukan wawancara kepada beberapa pelayan musik ibadah dan juga pemimpin gereja, termasuk di dalamnya sumber yang didapat penulis dari pengalaman di lapangan. Selain itu, penulis juga akan melengkapi penelitian ini melalui studi pustaka terhadap isu-isu terkait. Proses penelitian tersebut membuka wacana berpikir kita tentang musik tradisional. Melalui penjabaran analisis tentang tantangan dan peluang penggunaan musik tradisional, kita dapat semakin mengenal bahwa musik tradisional adalah warisan sejati yang dimiliki seseorang maupun komunitas. Musik tradisional merupakan sebuah cara untuk mengekspresikan Allah yang berinkarnasi yang patut kita rayakan dalam ibadah. Melalui tulisan ini, penulis berharap musik tradisional dapat semakin dihargai dan dilestarikan.
\end{abstract}

Kata kunci: gereja; ibadah; inkarnasi; musik; tradisional

\begin{abstract}
Indigenous music is currently an exciting subject to discuss, especially when it comes to Christian worship. Is indigenous music appropriate, or is it still relevant to use in Christian worship? Questions like this often arise in discussion. This question's answer is not easy because there are so many perspectives and disciplinary approaches that must be explored to provide the right solution. The research in this paper is to show the challenges and opportunities of using indigenous music, from a theological and musical perspective. The author uses the Church and Theological Seminaries as the scope of research because these two institutions are a place where the educational process can be applied and have a wider influence. To collect data in the field, the author conducted interviews with several worship music ministers and church leaders, including the author's sources, from her field experience. The authors will also complement this research through literature studies on related issues. The research process opens our thinking discourse about indigenous music. Through an elaborate analysis of the challenges and opportunities of using traditional music, we can increasingly recognize that traditional music is a real legacy that a person and community has. Indigenous music is a way to express God's incarnation that we should celebrate in worship. Through this paper, the writer hopes that indigenous music can be increasingly appreciated and preserved.
\end{abstract}

Keywords: church; worship; incarnation; music; traditional 


\section{Pendahuluan}

Sebelum membahas tantangan dan peluang penggunaan musik tradisional di Gereja dan Sekolah Tinggi Teologi, kita perlu menyatukan pemahaman tentang apa itu musik tradisional. Untuk memahami musik tradisional, salah satu pendekatan yang dapat digunakan adalah melalui studi etnomusikologi. Nakagawa menjelaskan bahwa istilah etnomusikologi merupakan gabungan dari tiga kata yaitu "ethnos", "mousike", dan "logos" (Yunani); ethnos artinya hidup bersama, yang kemudian berkembang menjadi bangsa atau etnis, mousike artinya musik, sedangkan logos artinya bahasa atau ilmu. Kemudian ketiga kata tersebut digabungkan menjadi ethnomusicology atau dalam bahasa Indonesia dikenal dengan etnomusikologi yang artinya musik bangsa atau etnis (Nakagawa, 1999, p. 2). Etnomusikologi memiliki keunikan yaitu sebagai disiplin yang menekankan pada musikologi komparatif dan antropologi musik (Mulyana, 2019, p. 3). Nakagawa menegaskan bahwa seorang etnomusikolog adalah peneliti yang membandingkan musik di berbagai belahan dunia. Sampai pada abad ke-19, musik diteliti hanya sebatas musik komparatif dan peneliti umumnya menggunakan teori musik Barat sehingga pengaruh musik Barat tidak dapat dihindari. Ternyata hal ini berdampak signifikan ketika mereka yang terbiasa mendengar tangga nada diatonis bertemu dengan tangga nada lokal, seperti slendro dan pelog pada Gamelan Jawa (Nakagawa, 1999, p. 2). Apalagi tangga nada lokal ini ternyata memiliki nilai-nilai filosofi yang melekat dalam etnis Jawa dan konsep kebudayaan mereka (Sasongko, 2019, p. 37).

Hal menarik lain tentang etnomusikologi adalah dalam penelitiannya tidak semua peneliti menekankan pada studi musik komparatif seperti yang dikembangkan oleh Jaap Kunst dan para pengikutnya. Beberapa peneliti lain menekankan pada antropologi musik, seperti Alan P. Merriam yang lebih menekankan pada penelitian lapangan bersama dengan masyarakat sekitar dan dinamika yang terjadi pada manusia yang menghasilkan suara (Mulyana, 2019, p. 3). Penelitian ini mengembangkan arti etnomusikologi, bukan hanya tentang musik tetapi sesuatu yang berhubungan dengan manusia, alam, hubungan, bahasa, adat istiadat, dan budaya. Pada titik ini, etnomusikologi memiliki celah masuk pada kajian tentang gereja dan ibadah, sebab mereka sama-sama berbicara tentang manusia serta bahasa dan budaya yang digunakan dalam merespons Sang Penyelenggara ibadah.

Beberapa definisi baru tentang etnomusikologi di abad ke-21 yang dikembangkan oleh Timothy Rice: "Etnomusikologi adalah studi tentang mengapa dan bagaimana, manusia 
itu bermusik." Lebih lanjut, "Etnomusikologi tidak memulai penelitian dengan penilaian tentang apa yang dianggap sebagai musik yang bagus atau musik yang layak dipelajari atau musik yang telah bertahan dalam ujian waktu." Sebaliknya, ia mengasumsikan bahwa kapan pun dan di mana pun manusia membuat dan mendengarkan musik, dengan ketajaman pengabdian dan perhatian yang mereka lakukan, maka sesuatu yang penting dan layak untuk dipelajari terus bermunculan" (Mulyana, 2019, p. 3).

Melalui dialektika dengan ilmu-ilmu lain seperti sosiologi, komunikasi, arkeologi, psikologi, ekologi, dan teologi menjadikan etnomusikologi sebagai kajian lintas disiplin ilmu. Secara khusus dalam penelitian ini, penulis akan melihat bagaimana etnomusikologi berdialog dengan teologi dalam rangka menganalisis penggunaan musik tradisional baik di gereja maupun di sekolah tinggi teologi. Mengapa dan bagaimana musik tradisional digunakan dalam Ibadah. Apa dampaknya bagi pertumbuhan iman jemaat? Bagaimana sekolah-sekolah teologi sebagai institusi yang membentuk dan menghasilkan pemimpin gereja dapat berperan dalam menanamkan pentingnya nilai-nilai lokal dan kesadaran pentingnya berteologi menurut konteks masing-masing. Penulis secara khusus akan menjabarkan tantangan-tantangan yang akan dihadapi di lapangan dalam penggunaan musik tradisional. Di balik tantangan tersebut tersimpan berjuta kesempatan. Penulis pun akan memperlihatkan kesempatan-kesempatan yang baik yang dapat muncul sebagai dampak penggunaan musik tradisional dalam ibadah.

\section{Ibadah Kristen: Partisipasi (Aktif) Komunitas}

Ibadah adalah sebuah perayaan umat. Perayaan ini adalah respons manusia atas apa yang diyakini dan diharapkan. Ibadah Kristen secara kongkrit merayakan kehadiran Allah Tritunggal, Allah yang turun ke dunia menyatu dalam kemanusiaan Yesus Kristus. Melalui inkarnasi Allah tidak lagi dipandang jauh, tak terjamah, melainkan justru sangat dekat, menjadi sama seperti manusia. Konsep inkarnasi ini sering disalahpahami, untuk itu Robert Webber membuat refleksi teologisnya terhadap apa yang disebut dengan inkarnasi: "Allah mengerjakan bagi kita apa yang kita tidak mampu kerjakan" (Webber, 2008, p. 35). Satu sisi, Inkarnasi Allah memberi pengharapan dan masa depan yang cerah bagi manusia yang berdosa. Kebahagiaan kita adalah menjadi bagian dalam kesatuan Allah Tritunggal: Bapa, Anak, dan Roh. Di sisi yang lain, melalui inkarnasi, kita tahu bahwa Allah menyatu dengan seluruh umat manusia dari segala suku, ras, dan budaya (Webber, 2008, p. 36). Inilah yang 
kita rayakan dalam ibadah. Oleh sebab itu ibadah perlu mengangkat hal-hal yang berhubungan dengan kebudayaan.

Ibadah Kristen secara eksplisit membahas partisipasi manusia dalam merayakan iman. Robert Webber mengatakan "Worship is a verb. It is not something done to us or for us, but by us" (Webber, 1999, p. 2). Ibadah adalah sebuah kata kerja, yang mana penyelenggaraannya akan melibatkan partisipasi aktif dari setiap orang. Ibadah bukan tontonan dan bukan pula sebuah pertunjukan. Tanpa partisipasi aktif dari umat, Ibadah tidak akan mencapai tujuannya. Partisipasi di sini adalah partisipasi aktif, seperti menghadap, memuji, mengaku, memberi, atau melakukan tindakan lain seperti melihat, mendengar, merasa, mengecap, mencium, dan bergerak (Webber, 1999, p. 2). Partisipasi ini mengandung nilai-nilai kemanusiaan. Suatu ibadah perlu mengakomodasi nilai-nilai tersebut sehingga tercapai apa yang dimaksud pada makna Liturgi (Leitourgia, dari bahasa Yunani). Defenisi liturgi ini terdiri dari 2 kata yaitu érgon (bekerja) dan laós (orang banyak), sehingga liturgi berarti pekerjaan orang banyak atau dengan kata lain pekerjaan yang dilakukan oleh orang banyak dan untuk kebutuhan orang banyak (komunitas) (Senn, 2012, p. 6). Dalam liturgi kita menemukan tidak hanya nilai spiritualitas tetapi juga nilai kemanusiaan dalam relasi dan keterhubungan dengan orang lain. Nilai kemanusiaan juga diwujudkan dalam keterhubungan dengan natur Allah dan iman Kristen, yang terwujud dalam partisipasi manusia di dalam Ibadah Kristen. Partisipasi ini dijabarkan oleh Craig Erickson (Erickson, 1989, p. 181-3), dalam beberapa tipe antara lain partisipasi spontan-lahir dari Allah yang Imanen; partisipasi hening-menghayati Allah yang transenden; partisipasi beragam-rasa-yang menggemakan kesucian Allah.

Nilai-nilai kemanusiaan sangat berhubungan dengan budaya. Oleh karena itu, ibadah tidak dapat lepas dari budaya, sebab ia berhubungan erat dengan nilai kemanusian. Ibadah harus merangkul setiap budaya yang ada dan menjadikannya sebagai nilai yang harus dijaga untuk menjaga keaslian ibadah itu sendiri. Dari sini kemudian kita mengenal istilah Inkulturasi Liturgi. Chupungco membuat definisi sederhana untuk menjelaskan Inkulturasi Ibadah sebagai "hubungan kreatif dan dinamis antara pesan kristiani dan budaya." Lebih lanjut ia menambahkan ada tiga ciri dari proses inkulturasi ini: pertama, inkulturasi adalah proses yang berkelanjutan dan relevan dengan setiap negara/wilayah tempat keyakinan itu ditanam; kedua, iman kristen tidak bisa ada kecuali dalam bentuk budaya; ketiga, antara iman dan budaya Kristen harus ada interaksi dan asimilasi timbal balik (Chupungco, 1992, p. 28-29). Dalam menjalankan hal ini masih banyak gereja yang keliru dan belum 
sepenuhnya menjalankan interaksi dengan seimbang. Pandopo mengatakan bahwa "Inkulturasi adalah suatu kewajiban bagi Gereja. Sekaligus perlu digarisbawahi bahwa inkulturasi tidak sama dengan hanya mengganti baju" (Pandopo, 1984, p. 91).

Proses inkulturasi memberi ruang partisipasi dan ekspresi yang otentik bagi umat. Yang mana hal ini dapat diwujudkan salah satunya melalui musik. Musik dapat digunakan untuk menggambarkan keindahan Allah yang kita imani. Begbie menuliskan, dalam musik ada dua tipe keindahan: pertama, keindahan yang hakiki, yang sudah ada secara alami, the beauty of "truthful" harmonies; kedua, keindahan buatan manusia. Dengan kata lain, jika dilihat dari sudut pandang teologis, ada keindahan yang dikaruniakan Tuhan kepada dunia, dan kita sebagai ciptaanNya, diundang untuk menghidupkan keindahan tersebut (Begbie, 2011, p. 83). Menggiatkan musik tradisional dalam ibadah adalah upaya untuk menghidupkan keindahan yang dikaruniakan Tuhan yang tampak dalam sebuah warisan budaya.

Pemahaman tentang hubungan dinamis antara budaya, iman Kristen, dan musik meyakinkan kita bahwa penggunaan musik tradisional, sebagai salah satu kekayaan peradaban dan anugerah dari Tuhan mestinya tidak dilarang dalam ibadah. Bahkan sebaliknya, musik tradisional justru akan menolong ibadah itu sendiri menemukan kedalamannya sebagai ruang komunal di mana manusia dapat mengekspresikan pujian dan rasa syukurnya dengan cara-cara yang autentik, yang sudah lama ditinggalkan oleh karena kekristenan selalu identik dengan budaya Barat.

\section{Musik Tradisional}

Sebelum membuat tulisan ini, peneliti beruntung karena dapat menghadiri festival musik etnik yang pertama kali diadakan di Jakarta oleh Pemerintah Kota Jakarta pada bulan September 2019. Program ini tidak hanya menghadirkan penampilan grup musik tradisional handal dari kota-kota di Indonesia, tetapi juga menyediakan ruang diskusi untuk membahas keberadaan musik tradisional yang mulai merosot bahkan hampir punah, seiring dengan muncul dan maraknya musik populer yang mendominasi industri musik Indonesia.

Dari festival itu, peneliti belajar dan mendengar bagaimana seniman tradisional mengekspresikan harta berharga yang terkandung dalam musik tradisional, antara lain nilai kemanusiaan yang terpancar melalui ekspresi dan komunikasi yang kuat antara para pemain musik melalui permainan musiknya. Awalnya satu instrumen memainkan pola musik yang 
dimainkan secara berulang-ulang, diikuti instrumen lainnya yang membuat pola musik yang sama atau pengembangan seraya menciptakan komunikasi non-verbal yang menciptakan harmoni yang indah dan menunjukkan sifat manusia yang selalu terhubung satu orang dengan orang lain.

Sayangnya saat ini musik tradisional seperti itu tidak terlalu diminati bahkan telah disalahartikan. Ada yang menganggapnya sebagai penyesatan (heresy) dan harus dipisahkan dan/atau dihilangkan karena tidak mengikuti kaidah-kaidah agama Kristen. Kita tahu bahwa agama Kristen tersebar dalam konteks kekristenan Barat. Gereja datang seolah membawa identitas baru, kemudian menghancurkan identitas lokal yang telah ada sebelumnya. Tidak sedikit kalangan Kristen berpikir bahwa pengalaman lokal adalah sesuatu yang harus dibuang ketika mereka memutuskan untuk menerima agama Kristen, ia dianggap tidak sejalan dengan apa yang disebut tradisi Kristen (Barat). Hal inilah yang disampaikan Loh sebagai tantangan musik kontekstual (baca: musik tradisional).

"Our basic challenge is this: How can we encourage an expression of Christian faith that is Asian, and not merely a transplantation of Western Christianity? In my view, contextualization is the approach we need to take in order to plant this new seed of the Gospel. In my first attempt, in 1984, to define the meaning of contextualization, I concluded that contextualization is, above all, the manifestation of the Imago Dei in humankind" (I to Loh, 2019).

Musik tradisional yang merupakan musik pemberian Tuhan kepada masyarakat lokal, sesungguhnya dapat dipahami sebagai sesuatu yang dapat menggambarkan sifat seseorang atau masyarakat tertentu. Sifat asli musik tradisional dapat membantu manusia dalam mengekspresikan semangat, serta melihat gambaran Allah yang sejati, sehingga dengan demikian ia mampu menciptakan ibadah sebagai respons manusia dengan cara yang autentik. Sebagaimana yang dikatakan Loh, upaya kontekstualisasi akan menolong mewujudkan hal tersebut. Pendekatan ilmu teologi kontekstual dapat menerjemahkan apa yang dimiliki oleh sebuah budaya untuk memahami kekristenan. Salah satu contoh yaitu memperkenalkan gamelan Jawa di sebuah jemaat yang tidak berlatarbelakang suku adalah sebuah upaya untuk mengindahkan jati diri Kristen, yang sesuai dengan teori model terjemahan yang dikembangkan oleh Bevans (Kristanto, 2019, p. 23).

Friesen dalam tulisannya mengemukakan bahwa diperlukan sebuah kematangan untuk dapat memilih, menganalisis musik tradisional yang tepat digunakan dalam sebuah komunitas Kristen yang terhubung dalam konteks budayanya masing-masing. Tidak semua istilah dan idiom dalam teks maupun musik tradisional tertentu dapat berfungsi dengan baik 
ketika digunakan sebagai nyanyian ibadah. Oleh sebab itu, sebelum digunakan, nyanyian tradisional perlu diuji coba supaya penggunaannya pada akhirnya menolong jemaat dalam beribadah (Friesen, 1982, p. 80-91).

Musik tradisional adalah sesuatu yang perlu dipertahankan, namun perlu dikaji secara menyeluruh sehingga dapat dipahami dengan baik dan penggunaannya dapat menolong orang beribadah. Identitas gereja semakin nyata lewat hubungan dinamis yang terbangun antara pelayanan gereja dengan budaya. Gereja dan sekolah-sekolah teologi perlu menyadari hal ini, agar mereka dapat menjadi agen pelestarian nilai-nilai yang terkandung dalam musik tradisional.

Menerapkan musik tradisional dalam ibadah akan menggiring pada berbagai macam tantangan dan peluang. Yang penulis tulis di sini adalah berdasarkan penelitian melalui jejak pendapat dari orang-orang di gereja seperti pendeta dan liturgis, dan juga melalui penelitian personal di lapangan.

\section{Tantangan}

Penerimaan musik tradisional di dalam ibadah tidak selalu lancar. Ada banyak tantangan yang dihadapi dan menjadi faktor penyebab musik tradisional ditinggalkan. Beberapa tantangan yang dihadapi antara lain:

1. Himne Barat dan nyanyian religi pop kontemporer sangat populer di gereja-gereja pada masa ini. Ketika diteliti, nyanyian itu bahkan telah digunakan pada ibadah setiap hari Minggu di semua generasi. Penyajian yang rutin dan terus-menerus menyebabkan musik ini menjadi lebih nyaman dan akrab di telinga masyarakat (jemaat gereja) dibandingkan musik lainnya yang jarang digunakan — salah satunya adalah musik tradisional rohani. Tidak jarang respons canggung dan merasa tidak nyaman muncul ketika nyanyian ibadah dimainkan dengan menggunakan musik tradisional. Rasa nyaman pada musik (musical taste) terbentuk dari gagasan tentang peran dan fungsi musik; misalnya jika kita lebih menikmati drama atau tarian, umumnya musik yang disukai adalah musik yang mendukung kegemaran kita tersebut. Selain itu, rasa itu muncul juga diakibatkan konteks budaya dan kelompok di mana kita bertumbuh; baik secara sosial dan status ekonomi (Wren, 2000, p. 134). Gereja yang berada di konteks perkotaan, di mana peradaban modern dan pengaruh populerisme begitu kuat, menjadi penentu bagaimana musik mengambil peranan. 
2. Kurangnya pemahaman dan referensi tentang indigenisasi, khususnya pada masyarakat perkotaan. Minim pengetahuan tentang musik tradisional dan bagaimana menggunakan alat musiknya menjadi tantangan yang tidak dapat dihindari. Ilmu musik tradisional dan juga upaya berteologi secara kontekstual akan menolong orang Kristen dalam memahami serta menerapkan musik tradisional. Di sinilah Sekolah Tinggi Teologi dan gereja harus mengambil perannya sebagai pusat pendidikan dan spiritual dengan membekali mahasiswa dengan pembelajaran yang mendukung upaya kontektualisasi. Begitupun gereja membekali jemaat dengan keindahan budaya, melalui ibadah-ibadah yang bernuansa budaya, dengan menyisipkan penjelasan tentang budaya tersebut.

3. Kurangnya sumber daya (instrumen dan partitur) musik yang asli. Tidak hanya ilmu seputar indigenisasi, tetapi mengadakan alat musik serta partitur musik juga menjadi tantangan tersendiri. Mengaransemen musik daerah tidak semudah mengaransemen himne Barat/lagu religi populer yang memiliki bentuk musik universal dan notasi standar. Gereja dan Sekolah Tinggi Teologi, terutama yang mewarisi tradisi Barat, jarang bersentuhan dengan tradisi dan alat musik tradisional. Selain karena biaya pengadaannya tidak murah, mengakomodasi dan mendatangkan seniman daerah yang benar-benar menguasai musik tradisional atau etnomusikolog yang dapat menjelaskan serta memainkan musik tradisional dengan cara yang otentik, juga menjadi tantangan tersendiri. Ini memerlukan usaha dan keseriusan serta biaya yang cukup besar. Sekolah Tinggi Filsafat Teologi Jakarta—institusi tempat penulis mengajar saat ini-berupaya mengumpulkan beberapa alat musik tradisional dari semua suku di Indonesia, walaupun belum semua, seperti tifa (Ambon), angklung (Sunda), gamelan (Jawa), gambang (Jawa Barat), calong (Sulawesi Barat). Hal ini dilakukan guna mengakomodasi penggunaan musik tradisional dalam ibadah maupun studi mahasiswa yang berhubungan dengan indigenisasi. Hal ini dirasa cukup menolong mahasiswa untuk melestarikan musik tradisional.

4. Nyanyian tradisional memiliki modalitas dan istilah yang khas. Loh mengatakan beberapa budaya di Asia gemar menyanyikan lagu dengan suku kata non-leksikal (suku kata yang berasal dan berakar pada tradisi setempat).

"Cultures in Asia like to sing songs with non-lexical syllables. They are vocables or "untalkables," words or syllables without specific meaning. They gain sense from the title, the purpose or context, words sung before or after, or the singer's mood and imagination. I propose that singing in non-lexical syllables may be comparable to St. Paul's idea of "sighs too deep for words" (Rom 8:27); that is, 
one may express something inexpressible. This can be further confirmed from the contemporary view of the Jewish tradition, as was pointed out recently by a Jewish cantor who said that the best kind of singing is wordless, which expresses the deepest and inner personal feelings." (I to loh, 2019)

Loh menganggap suku kata non-leksikal ini merupakan kekuatan dari syair nyanyian tradisional, yang mengungkapkan perasaan pribadi yang paling dalam dari budaya setempat. Sayangnya, beberapa orang melihat suku kata non-leksikal ini sebagai istilah yang sulit untuk dipahami dan tidak dapat digunakan secara umum.

5. Banyak masyarakat Indonesia yang percaya bahwa musik tradisional hanya dibuat untuk ritual budaya, yang menurut beberapa anggapan sangat berbeda dengan ibadah Kristen. Itulah sebabnya beberapa orang bahkan ragu menggunakannya dalam ibadah Kristen. Bahkan ada yang mengatakan itu sesat. Catherine Hodges dalam jurnalnya, pernah menyaksikan dua argumentasi yang kontradiktif ketika dia mengikuti sebuah prosesi ritual dengan kain adat Batak dengan musik dan tarian. Dia mencoba membandingkan dua tanggapan tersebut dengan demikian: seorang siswa (bersuku Batak) berkata, "mendengar musik dan melihat tarian dari Batak, saya benar-benar merasakan-untuk pertama kalinya - bahwa Yesus datang ke bumi untuk saya, seorang Batak." Sedangkan yang lainnya, seorang rekan dosen mengatakan "Itu sesat!". Dosen ini kebetulan adalah generasi yang lebih tua dari siswa dan cukup tua untuk mengasosiasikan musik dan tarian dengan praktik pemujaan animistik (Fortunato, 2006, p. 167). Inilah tantangan di tengahtengah gereja yang tidak dapat dihindari, yang bahkan sampai saat ini kejadian seperti itu masih terus berlangsung.

\section{Peluang}

Musik merupakan media yang baik untuk digunakan sebagai pengajaran. Musik dapat mengomunikasikan pesan gerejawi, bahkan terkadang melampaui kata yang terbatas. Selain itu, jika dibandingkan dengan mendengar kotbah, dengan bernyanyi umat dapat terlibat lebih aktif. Tidak hanya sampai di situ, melodi yang tinggal dalam memori akan mengikat kita pada pesan gerejawi maupun Firman yang kita terima dan ini membuat kita merasa terus dekat, secara hati dan jiwa, dengan persekutuan (gereja) (Eskew dan McElrath, 1989, p. 277). Dengan demikian, dalam musik selalu ada peluang yang baik. Selain tantangan-yang tidak dapat kita hindari-kita juga dapat menemukan peluang-peluang 
yang baik dalam menggunakan musik tradisional. Inilah harapan dan kabar baik yang perlu disebarkan dalam rangka membangkitkan apresiasi terhadap musik tradisional:

1. Jenis musik ini memberikan kesegaran baru dalam ibadah. Musik tradisional dapat menghilangkan gagasan bahwa musik Barat adalah satu-satunya musik yang mendapat tempat dalam ibadah Kristen di seluruh dunia. Ketika beberapa gereja di Indonesia telah menggunakan musik tradisional dalam ibadahnya, ternyata hal itu justru membantu jemaat untuk mengalami ibadah dan penyembahan secara berbeda, lebih autentik dan bersentuhan langsung dengan identitas kesukuan yang tidak dapat dipungkiri tetap mendarahdaging sekalipun sudah bercampur dengan budaya modern. Upaya untuk memperkenalkan nyanyian tradisional dan menggunakannya dalam ibadah perlu senantiasa menjadi agenda Sekolah-sekolah Teologi, supaya semakin banyak gereja yang mengenal dan menemukan jati diri jemaat melalui musik tradisional tersebut.

2. Musik tradisional sebagai musik yang lahir dari identitas personal dapat digunakan untuk misi dan penginjilan. Para misionaris telah mengamati bahwa musik tradisional sebagian besar adalah berbentuk "proklamasi", dan karenanya sangat cocok untuk penginjilan dan pengajaran (Fortunato, 2006, p. 170). Musik khusus ini dapat digunakan untuk menyampaikan pesan Injil dan sarana yang tepat untuk penginjilan.

3. Musik tradisional juga membantu gereja menjadi lebih autentik dalam ibadah mereka. Mazmur 86: 9 mengatakan, "Semua bangsa yang telah kau buat akan datang dan menyembah di hadapanmu, ya Tuhan; mereka akan membawa kemuliaan bagi namaMu." Tuhan dimuliakan ketika Dia menerima respons umat dari keberadaannya yang sejati dan terdalam. Ibadah yang demikian tidak mungkin disebut sesat, pasalnya justru di dalam ibadah tersebut kita dapat merasakan kesucian dan keindahan Allah yang sejati. Inilah yang disebut sebagai cita rasa multikultural surgawi yang suatu hari akan kita rasakan (Fortunato, 2006, p. 170).

4. Memperkenalkan musik tradisional melalui perkuliahan maupun festival musik (yang dilakukan oleh Gereja atau Sekolah Teologi) dapat menjadi model edukasi. Dari ajang ini kita dapat menemukan komunitas musik yang "bergairah", yaitu mereka yang tertarik dengan musik tradisional dan kemudian mengembangkannya sesuai dengan kebutuhan ibadah.

5. Musik tradisional juga merupakan musik yang dapat diperkenalkan kepada anak-anak dan remaja di gereja. Selain karena pola yang sederhana, gereja juga perlu memberikan pemahaman tentang budaya dan gereja sejak dini kepada anak-anak. Melalui kelompok 
musik usia dini, musik tradisional akan dapat dilestarikan dan akan tetap digunakan di masa depan.

6. Ada beberapa upaya dialogis yang dapat dilakukan di dalam musik tradisional dan musik populer yaitu mengumpulkan beberapa ide dan inovasi yang diambil dari musik tradisional dan digabungkan dengan musik modern, seperti musik pop, rock, funk, dan jazz. Ini memberikan warna yang khas dan canggih dalam konteks kontemporer ini. Hal yang paling berharga adalah musik inovatif ini dapat menyentuh generasi muda dan membantu mereka untuk bertumbuh dalam identitas sejatinya.

\section{Kesimpulan}

Musik tradisional bukanlah genre atau bentuk musik yang menjadi pilihan ketika kita harus memilih musik apa yang tepat untuk digunakan dalam ibadah. Sebaliknya, musik tradisional—dalam segala aspek-aspeknya — perlu dihadirkan sebagai cara menolong ibadah mencapai tujuannya, yaitu ketika umat dapat berpartisipasi aktif secara autentik. Partisipasi autentik ini akan terwujud melalui dinamika yang terjalin antara identitas manusia yang terikat dengan konteks tertentu dengan kebenaran yang sejati dalam iman Kristen. Dengan demikian ibadah Kristen perlu mendukung penggunaan musik tradisional, sehingga dapat mewujudkan partisipasinya dalam mengkaryakan keindahan yang telah dianugerahkan Tuhan kepada dunia.

Menghadirkan musik tradisional dalam ibadah saat ini memang tidaklah mudah, ada banyak tantangan yang harus dihadapi. Namun bukan berarti kita menjadi apatis dan tidak ingin menggunakannya sama sekali dalam ibadah. Tantangan dapat dijadikan sebagai tolok ukur, apa saja kemudian yang harus diantisipasi ketika hendak menghadirkan musik tradisional dalam ibadah. Di samping tantangan, ada banyak peluang yang dapat kita lihat di dalam musik dan penggunaan musik tradisional dalam ibadah Kristen. Peluang-peluang ini melahirkan asa bahwa musik tradisional dapat membangun spiritualitas umat, serta menolong gereja dalam memenuhi fungsi dan peranannya di dalam penginjilan dan proses edukasi. Gereja dan Sekolah-sekolah Tinggi Teologi adalah tempat yang tepat untuk menjadi basis di mana generasi penerus pimpinan gereja dapat diperlengkapi. Oleh sebab itu, baik gereja dan sekolah-sekolah tinggi teologi perlu memerhatikan tantangan dan peluang yang ada dan dapat bersama-sama mendukung, mengapresiasi, bahkan memaksimalkan penggunaan musik tradisional. Misi Allah yang berinkarnasi tetap harus dijalankan dan ini 
menjadi tugas gereja untuk menerjemahkan Allah yang berinkarnasi dalam segala konteks yang ada. Di sinilah musik tradisional, sejatinya dapat mendukung dan memaksimalkan pelayanan gereja.

\section{Kepustakaan}

Begbie, Jeremy S. (2011). Resonant Witness: Conversations Between Music and Theology. Michigan: William B. Eerdmans Publishing Company.

Chupungco, Anscar. (1992). Liturgical Inculturation Sacramentals, Religiosity, and Catechesis. Minnesota: The Liturgical Press.

Eskew, Harry and Hugh T. McElrath. (1995). Sing with Understanding: An Introduction to Christian Hymnology. Nashville: Church Street Press.

Fortunato, Frank, et. al. (2006). All the World is Singing: Glorifying God through the Worship Music of the Nations. Amerika: Athentic Publishing.

Friesen, A. W. D. (1982). A methodology in the development of indigenous hymnody. Missiology, 10(1), 83-96.

I to Loh. Contextualization versus Globalization: A Glimpse of Sounds and Symbols in Asian Worship. Diakses pada tanggal 10 September 2019, dari https://ism.yale.edu/sites/default/files/files/Contextualization\%20versus\%20Globaliz ation.pdf.

Kristanto, A. (2019). KONTEKSTUALISASI GAMELAN JAWA DI GEREJA BAPTIS INDONESIA (GBI) NGEMBAK. Tonika: Jurnal Penelitian Dan Pengkajian Seni, 2(1), 19-31. https://doi.org/10.37368/tonika.v2i1.40

Mulyana, Anton Rustandi. (2019). Etnomusikologi di antara keilmuan murni dan terapan. Ceramah, Graha Bakti Budaya, Jakarta. 10 September 2019.

Nakagawa, Shin. (1999). Musik dan Kosmos: Sebuah Pengantar Etnomusikologi. Jakarta: Yayasan Obor Indonesia.

Pandopo, H.A. (1984). Menggubah Nyanyian Jemaat. Jakarta: BPK Gunung Mulia.

Sasongko, M. (2019). MUSIK ETNIK DAN PENGEMBANGAN MUSIK GEREJA. Tonika: Jurnal Penelitian Dan Pengkajian Seni,2(1), 32-47. https://doi.org/10.37368/tonika.v2i1.41

Senn, Frank C. (2012). Introduction to Christian Liturgy. Minneapolis: Fortress Press.

Webber, Robert E. (1999). Worship is a Verb: Eight Principles for Transforming Worship. Massachusetts: Hendrickson Publishers.

. (2008). Ancient-Future Worship: Proclaiming and Enacting God's Narrative. Michigan: Baker Books.

Wren, Brian. (2000). Praying Twice: The Music and Words of Congregational Song. Louisville: Westminster John Knox Press. 